\title{
PERBEDAAN EKSPRESI PROTEIN CYCLIN D1 ANTARA ADENOMA DAN ADENOKARSINOMA KOLOREKTAL, SERTA KORELASINYA DENGAN GRADING DAN STADIUM TUMOR
}

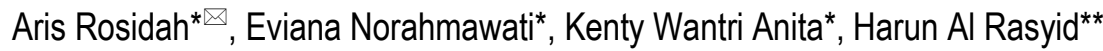

\begin{abstract}
Abstrak
Sebagian besar karsinoma kolorektal adalah adenokarsinoma, dan lebih dari 95\% karsinoma kolorektal diawali oleh lesi prekursor yaitu adenoma. Risiko suatu adenoma berubah menjadi suatu karsinoma akan lebih tinggi pada adenoma dengan ukuran lebih dari $1 \mathrm{~cm}$, tipe villous, dan disertai displasia high grade. Telah diketahui bahwa grading dan stadium merupakan faktor prognostik penting baik pada adenoma maupun adenokarsinoma. Perkembangan adenoma menjadi adenokarsinoma melibatkan peran banyak gen dan protein, salah satunya cyclin D1 yang berperan meningkatkan proliferasi sel, angiogenesis dan invasi sel. Penelitian ini bertujuan untuk mengetahui perbedaan ekspresi cyclin D1 antara adenoma dan adenokarsinoma kolorektal, serta hubungannya dengan grading dan stadium tumor. Lalu, ditentukan 30 sampel untuk masing-masing adenoma dan adenokarsinoma yang diambil dari Instalasi Patologi Anatomi RS. dr. Saiful Anwar Malang. Keseluruhan sampel dilakukan pulasan imunohistokimia dengan antibodi cyclin D1 kemudian dihitung persentase ekspresinya, dan dianalisis hubungan antara cyclin D1 tersebut dengan grading pada adenoma dan grading serta stadium pada adenokarsinoma. Hasil penelitian menunjukkan terdapat perbedaan ekspresi cyclin D1 yang bermakna antara kelompok adenoma dan adenokarsinoma dengan $p<0,01$. Tidak terdapat hubungan yang bermakna antara ekspresi cyclin D1 dengan grading adenoma serta grading dan stadium adenokarsinoma ( $p>0,05)$. Kesimpulan penelitian ini adalah ekspresi cyclin D1 dapat digunakan untuk membedakan antara adenoma dan adenokarsinoma, tetapi ekspresi tersebut tidak berhubungan dengan grading dan stadium tumor.
\end{abstract}

Kata kunci: adenokarsinoma, cyclin D1, grading, kolorektal, stadium.

\section{DIFFERENCES OF CYCLIN D1 EXPRESSION BETWEEN COLORECTAL ADENOMA AND ADENOCARCINOMA, AND ITS CORRELATION WITH GRADING AND STAGING OF TUMOR}

\begin{abstract}
Most colorectal carcinomas are adenocarcinomas, and more than $95 \%$ of colorectal carcinomas are preceded by precursor lesions as adenomas. The risk of an adenoma turning into a carcinoma will be higher in adenomas with a size of more than $1 \mathrm{~cm}$, villous type, and high grade dysplasia. It is known that grading and staging are important prognostic factors in both adenomas and adenocarcinomas. The development of adenomas into adenocarcinomas involves the role of many genes and proteins, one of which is cyclin D1 which plays a role in cell proliferation, angiogenesis and cell invasion. This study aims to determine differences in cyclin D1 expression between colorectal adenomas and adenocarcinomas, as well as its correlation between grading and stage. Thirty samples were determined for each adenoma and adenocarcinoma that obtained from the Anatomical Pathology Installation of dr. Saiful Anwar Hospital Malang. All samples were examined immunohistochemically with cyclin D1 antibodies, then calculated the expression, and also analyzed the correlation between cyclin D1 with grading on adenoma and grading and stage on adenocarcinoma. The results showed that there was a significant difference in the expression of cyclin D1 between the adenoma and adenocarcinoma groups with $p<0.01$. There was no significant correlation between cyclin D1 expression with grading of adenoma and grading and stage of adenocarcinoma $(p>0.05)$. The conclusion is cyclin D1 expression can be used to distinguish between adenomas and adenocarcinomas, but this expression not associated with grading and stadium of tumor.
\end{abstract}

Keywords: adenocarcinoma, colorectal, cyclin D1, grading, staging.

* Departemen Patologi Anatomik, Fakultas Kedokteran, Universitas Brawijaya-RSUD dr. Saiful Anwar Malang

${ }^{* *}$ Departemen IImu Kesehatan Masyarakat dan Kedokteran Pencegahan, Fakultas Kedokteran,

Universitas Brawijaya

凶E-mail: rosie_21dr@yahoo.co.id 


\section{Pendahuluan}

Kanker kolorektal merupakan keganasan kedua terbanyak pada wanita $(614.000$ kasus, 9,2\% dari seluruh kanker) dan keganasan ketiga pada laki-laki (746.000 kasus, $10 \%$ dari total keganasan) di seluruh dunia. ${ }^{1,2}$ Kanker kolorektal diawali dari lesi prekursor yang pada umumnya berjalan lambat sampai menjadi suatu keganasan. Lesi prekursor tersebut meliputi adenoma konvensional (adenomatous polyp), serrated polyp, lesi yang terdapat pada beberapa sindrom poliposis yaitu Familial Adematous Polyposis (FAP), Lynch syndrome, Peutz-Jeghers syndrome dan Juvenile Polyposis Syndrome, serta lesi pada Irritable Bowel Disease (IBD) yang disertai displasia. ${ }^{3}$

Perjalanan dari epitel kolon normal menjadi lesi prekursor dan akhirnya menjadi suatu kanker melibatkan dua jalur utama. Pertama jalur klasik, melibatkan perubahan epitel normal menjadi suatu adenoma dan akan menjadi karsinoma. Kedua, jalur alternatif, yang melibatkan perubahan epitel normal menjadi serrated polyp sebelum menjadi suatu karsinoma. Meskipun hanya sekitar $10 \%$ dari adenoma kolorektal, beberapa penelitian me-nyebutkan bahwa $80 \%$ dari kasus kanker kolorektal berawal dari adenoma, sedangkan sisanya $20 \%$ berasal dari Sessile Serrated Polyp (SSP). Risiko adenoma menjadi suatu karsinoma lebih tinggi pada adenoma dengan ukuran $>1 \mathrm{~cm}$, gambaran villous dan adenoma yang disertai displasia berat. 4,5,6,7

Salah satu protein yang berperan dalam perkembangan epitel kolon normal menjadi suatu lesi adenoma dan akhirnya menjadi suatu karsinoma adalah cyclin D1. Cyclin D1 mempunyai banyak fungsi sebagai onkogen, yaitu mengatur beberapa proses transformasi sel menjadi ganas meliputi pertumbuhan abnormal, angiogenesis dan resistensi terhadap apoptosis.

Cyclin D1 mempunyai peran penting da- lam regulasi mitosis, khususnya pada progresi tahap G1 menuju tahap S dalam siklus sel, serta mempunyai efek meningkatkan Vascular Endothelial Growth Factor (VEGF) dan menghambat TSP-1 (Thrombospondin-1) yang menyebabkan peningkatan angiogenesis, dimana kedua hal tersebut menyebabkan terjadinya pertumbuhan sel meningkat. Selain itu, cyclin D1 juga dihubungkan dengan peningkatan Transforming Growth Factor Beta (TGF $\beta$ ) ser-ta penghambatan terhadap sinyal Rho/ROCK dan TSP-1, yang akan menyebabkan proses invasi dan metastasis dari sel ganas. 8,9,10

Lebih dari sepertiga kanker kolorektal menunjukkan overekspresi dari cyclin D1, meskipun peran cyclin D1 pada siklus sel sudah jelas, namun terdapat kontroversi tentang hubungan antara ekspresi cyclin D1 dengan prognosis kanker kolorektal. Beberapa studi menunjukkan bahwa ekspresi cyclin D1 berhubungan dengan prognosis buruk, sedangkan studi lain menunjukkan ekspresi protein tersebut berhubungan dengan prognosis baik, dan beberapa penelitian lain mengemukakan tidak ada hubungan antara ekspresi cyclin D1 dengan prognosis pasien kanker kolorektal. ${ }^{11,12}$

Penentuan prognosis dari adenoma dan adenokarsinoma di antaranya adalah dengan melihat grading dan stadium tumor. Grading ditentukan dari derajat diferensiasi sel, sedangkan stadium berdasarkan klasifikasi Dukes yang dilihat dari kedalaman tumor menembus dinding usus, ada tidaknya invasi pada kelenjar getah bening, dan ada tidaknya metastasis jauh.

Berdasarkan berbagai teori tersebut, maka penelitian ini bertujuan untuk mengetahui perbedaan ekspresi cyclin D1 antara adenoma dan adenokarsinoma kolorektal, sehingga ekspresinya dapat digunakan untuk membedakan keduanya. Kepentingan klinis yang diharapkan adalah apabila ahli patologi mendapatkan sediaan biopsi dengan kecurigaan klinis suatu adenoma, namun secara 
histopatologis terdapat hasil yang meragukan suatu lesi yag jinak, maka pemeriksaan ekspresi cyclin D1 dapat digunakan untuk membantu diagnosis agar menjadi kewaspadaan bagi klinisi apabila kemungkinan lesi mengarah ke suatu keganasan. Selain itu, penelitian tentang cyclin D1 pada kasus adenoma dan adenokarsinoma kolorektal di Indonesia juga belum pernah dipublikasikan. Penelitian ini juga bertujuan mengetahui hubungan protein cyclin D1 dengan profil klinikopatologi keduanya, dalam hal ini grading dan stadium tumor. Penentuan grading pada adenoma penting karena termasuk salah satu indikator suatu adenoma mengalami progresifitas menjadi karsinoma. Sedangkan stadium pada adenokarsinoma merupakan salah satu bahan pertimbangan penentuan terapi oleh klinisi.

\section{Bahan dan Metode}

Penelitian ini bersifat observasional analitik dengan desain cross-sectional. Sampel dan kegiatan penelitian diperoleh dan dilakukan di Instalasi Patologi Anatomi RSUD dr Saiful Anwar Malang, dari blok parafin pasien yang didiagnosis adenoma dan adenokarsinoma kolorektal antara tahun 2016-2019. Penelitian ini telah mendapatkan persetujuan laik etik dari Komisi Etik Penelitian Kesehatan RS. dr. Saiful Anwar Malang dengan nomer surat 400/262/K.3/302/2019.

Berdasarkan kriteria inklusi dan eksklusi serta penghitungan besar sampel, didapatkan masing-masing 30 sampel setiap kelompok, sehingga sampel total adalah 60 . Sediaan dengan pewarnaan hematoksilin-eosin (HE) yang sudah ada sebelumnya dikumpulkan dan dievaluasi ulang untuk penentuan grading berdasarkan kriteria WHO dan sta-diumnya berdasarkan klasifikasi Dukes. Dari sediaan blok parafin tersebut dilakukan pulasan imunohistokimia dengan antibodi rabbit monoclonal anti-human cyclin D1 antibody (Biogenex; Cat: NU815-UC), dengan pengen- ceran 1:30.

Pulasan imunohistokimia menggunakan metode streptavidin-biotin kompleks, dengan kontrol menggunakan sediaan karsinoma payudara. Kemudian hasil pulasan diamati di bawah mikroskop cahaya binokuler Olymphus BX43 dan dilakukan penghitungan persentase protein cyclin D1 dengan bantuan program hsel. Penghitungan sel yang terpulas coklat pada inti sel kolumnar neoplastik di kelenjar, pada 1000 sel dari 5 lapang pandang besar (400x) secara acak (masing-masing lapang pandang besar diambil $200 \mathrm{sel}) .{ }^{13} \mathrm{Ha}-$ sil penghitungan dinyatakan dalam persentase. Slide preparat dibaca oleh 1 ahli patologi dan 1 peneliti tanpa mengetahui data klinis maupun histopatologisnya (double blind).

Analisis data untuk melihat perbedaan ekspresi antar kelompok menggunakan independent $t$-test untuk data yang terdistribusi normal dan homogen. Sedangkan untuk melihat hubungan cyclin D1 dengan grading dan stadium tumor digunakan uji korelasi dengan Spearman. Analisis statistik menggunakan perangkat lunak statistical package for social sciences (SPSS) 20.0.

\section{Hasil}

\section{Karakteristik Sampel}

Sampel total pasien yang didapatkan berjumlah 60 , dengan rincian kasus adenoma 30 dan adenokarsinoma 30, yang telah memenuhi kriteria inklusi. Karakteristik klinikopatologi sampel dapat dilihat pada Tabel 1. Dari 30 sampel adenoma didapatkan sebanyak $16(53,3 \%)$ pria dan $14(46,7 \%)$ wanita, dengan rentang usia mulai 2-82 tahun, dengan rerata $54,67 \pm 19,11$ tahun, dan median usia 55 tahun. Lokasi tersering didapatkan pada daerah rektosigmoid sebanyak 17 pasien (56,7\%). Gambaran histopatologi tersering adalah tipe tubular sebanyak 16 pasien $(53,3 \%)$, sedangkan ber-dasarkan grading, sebanyak 23 pasien $(76,7 \%)$ low grade, 7 pasien $(23,3 \%)$ high grade. 
Dari 30 sampel kasus adenokarsinoma, didapatkan sebanyak 12 pasien pria $(40 \%)$ dan 18 wanita $(60 \%)$, dengan rentang usia mulai 31 sampai dengan 78 tahun dengan rerata 55,77+12,07 tahun, dan median usia 55,5 tahun. Lokasi tersering didapatkan pada daerah colon ascenden sebanyak 14 pasien $(46,7 \%)$, gambaran histopatologi terbanyak adalah well differentiated sebesar 21 pasien
(70\%), sedangkan grading terbanyak adalah low grade sebanyak 27 pasien $(90 \%)$ dan high grade 3 pasien (10\%). Stadium berdasarkan klasifikasi Dukes terbanyak adalah Dukes B2 sebesar 18 pasien (60\%), Dukes C2 dan D masing-masing 4 pasien $(13,3 \%)$, Dukes B1 dan $\mathrm{C} 1$ masing-masing 2 pasien $(6,7 \%)$.

Tabel 1. Karakteristik klinikopatologi sampel penelitian

\begin{tabular}{|c|c|c|}
\hline \multirow[t]{2}{*}{ Parameter } & Adenoma & Adenokarsinoma \\
\hline & Frekuensi (\%) & Frekuensi $(\%)$ \\
\hline \multicolumn{3}{|l|}{ Jenis kelamin } \\
\hline Laki-laki & $16(53.3)$ & $12(40)$ \\
\hline Perempuan & $14(46.7)$ & $18(60)$ \\
\hline \multicolumn{3}{|l|}{ Usia } \\
\hline$<50$ tahun & $11(36.7)$ & $11(36.7)$ \\
\hline$>51$ tahun & $19(63.3)$ & $19(63.3)$ \\
\hline \multicolumn{3}{|l|}{ Lokasi } \\
\hline Colon ascenden & $7(23.3)$ & $14(46.7)$ \\
\hline Colon transversum & $1(3.3)$ & $3(10)$ \\
\hline Colon Descenden & $5(16.7)$ & $4(13.3)$ \\
\hline Rectosigmoid & $17(56.7)$ & $9(30)$ \\
\hline \multicolumn{3}{|l|}{ Tipe Histopatologi } \\
\hline Tubular & $16(53.3)$ & - \\
\hline Tubulovillous & $5(16.7)$ & - \\
\hline Villous & $9(30)$ & - \\
\hline \multicolumn{3}{|l|}{ Derajat diferensiasi } \\
\hline Well differentiated & - & $21(70)$ \\
\hline Moderately differentiated & - & $6(20)$ \\
\hline Poorly differentiated & - & $3(10)$ \\
\hline \multicolumn{3}{|l|}{ Grading } \\
\hline Low grading & $23(76.7)$ & $27(90)$ \\
\hline High grading & $7(23.3)$ & $3(10)$ \\
\hline \multicolumn{3}{|l|}{ Stadium } \\
\hline Dukes B1 & - & $2(6.7)$ \\
\hline Dukes B2 & - & $18(60)$ \\
\hline Dukes C1 & - & $2(6.7)$ \\
\hline Dukes C2 & - & $4(13.3)$ \\
\hline Dukes D & - & $4(13.3)$ \\
\hline
\end{tabular}

Keterangan: Angka yang dicetak tebal menunjukkan jumlah terbanyak dari masing-masing kelompok sesuai parameter. 
Perbedaan Ekspresi Protein Cyclin D1 antara Adenoma dan Adenokarsinoma Kolorektal

Rerata ekspresi protein cyclin D1 pada adenoma adalah sebesar $31,38 \pm 12,12 \%$, dengan nilai range antara 11,3-64,3\%. Pada kasus adenokarsinoma kolorektal didapatkan ekspresi protein cyclin D1 sebesar $46,70 \pm 12,92 \%$, dengan rentang antara 16,2-
$70,8 \%$. Data yang didapatkan terdistribusi normal dan homogen, sehingga untuk melihat perbedaan kedua kelompok dianalisis dengan uji parametrik, yaitu independent $t$-test. Hasil menunjukkan nilai $p<0,01$, sehingga dapat diartikan bahwa terdapat perbedaan ekspresi yang signifikan antara kelompok adenoma dan adenokarsinoma (Tabel 2).

Tabel 2. Hasil analisis statistik perbedaan ekspresi protein cyclin D1 antara kelompok adenoma dan adenokarsinoma kolorektal

\begin{tabular}{lccc}
\hline \multicolumn{1}{c}{ Kelompok Sampel } & $\mathrm{n}$ & $\begin{array}{c}\text { Ekspresi Cyclin D1 (\%) } \\
\text { Mean+SD }\end{array}$ & Independent T-Test \\
\hline Adenoma & 30 & $31,38+12,12$ & $\mathrm{p}<0,01$ \\
Adenokarsinoma & 30 & $46,70+12,92$ & \\
\hline
\end{tabular}

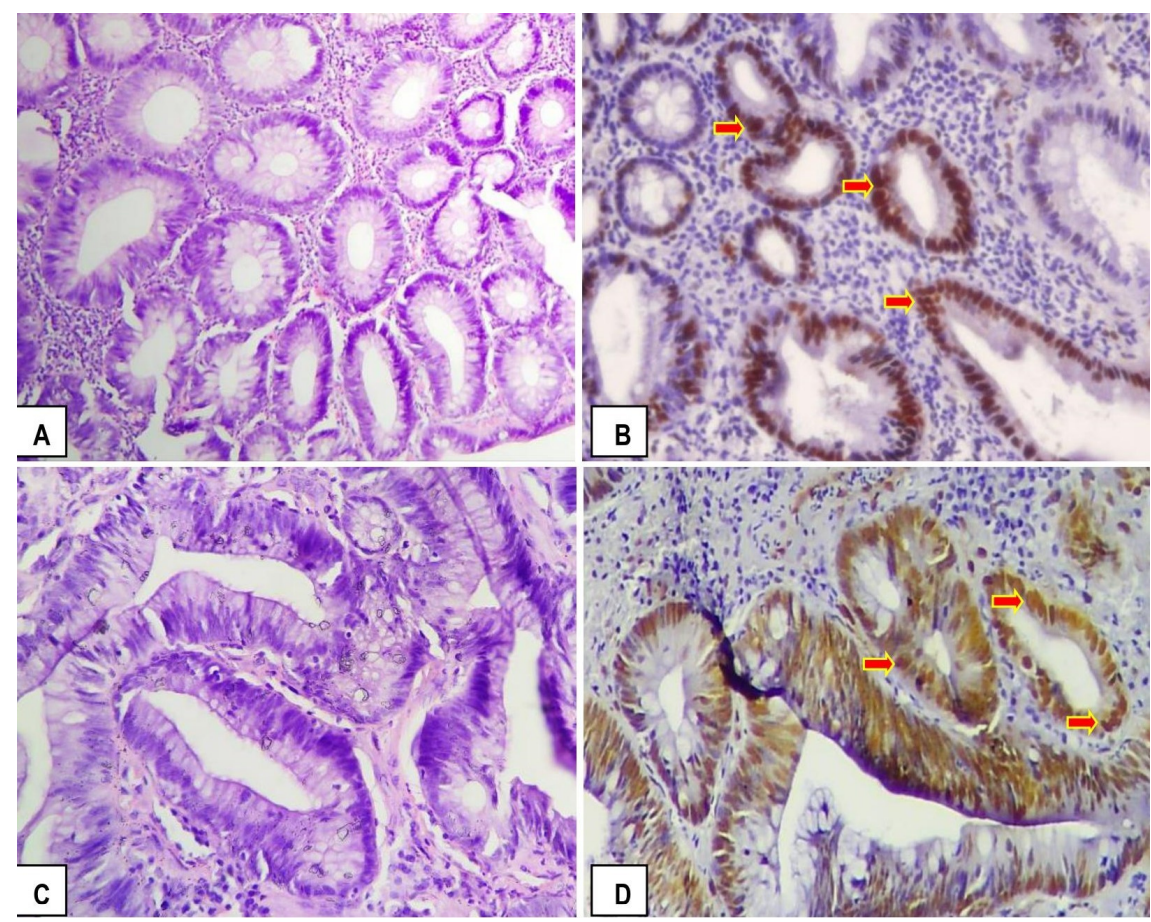

Gambar 1. Pulasan hematoksilin-eosin (HE) dan imunohistokimia dengan antibodi cyclin D1 pada kelompok adenoma low grade (A,B) dan high grade (C,D) (400x).

Keterangan: A. Pulasan HE dari adenoma low grade; B. Ekspresi cyclin D1 pada adenoma low grade, terpulas coklat pada inti sel tumor (tanda panah merah); C. Pulasan HE dari adenoma high grade; D. Ekspresi cyclin D1 pada adenoma high grade, terpulas coklat pada inti sel tumor (tanda panah merah). 


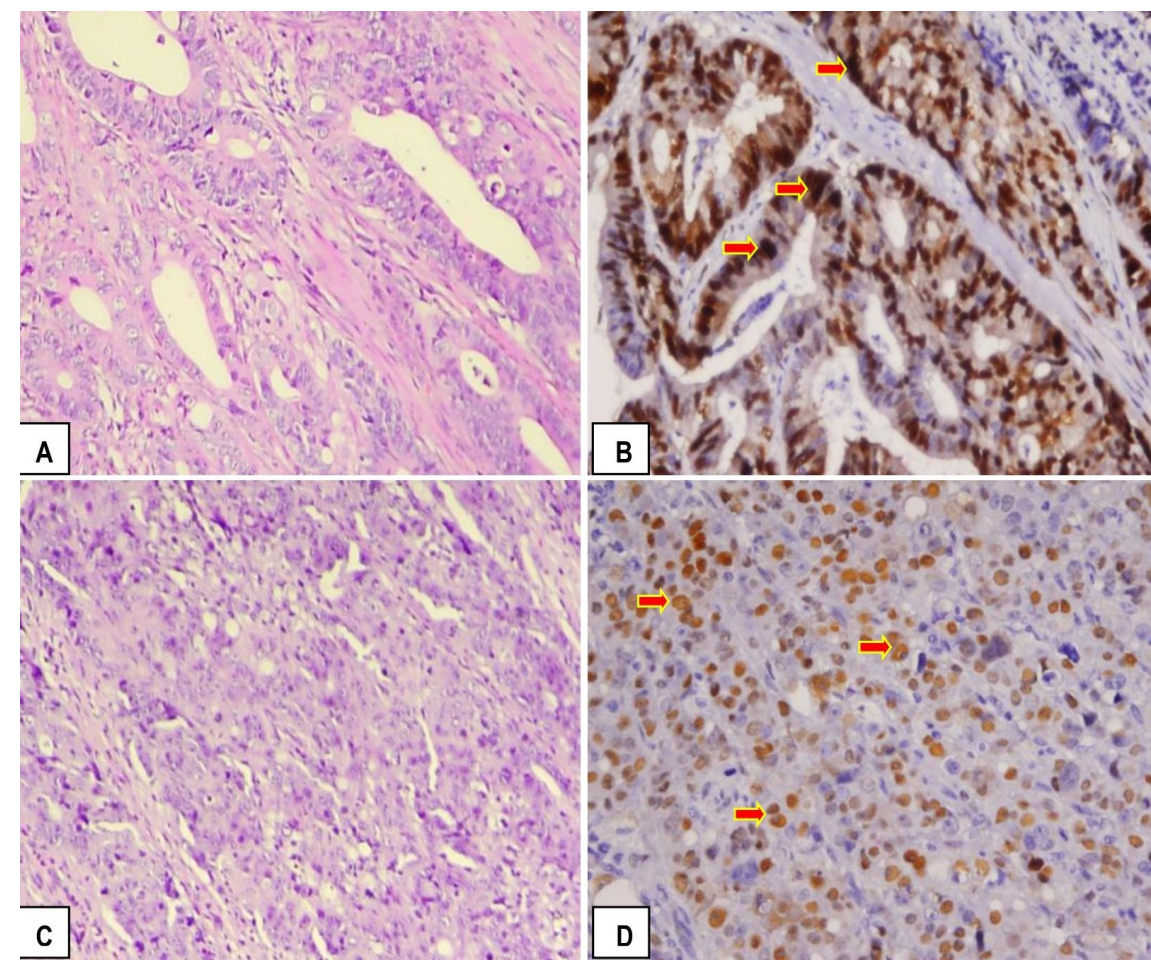

Gambar 2. Pulasan hematoksilin-eosin (HE) dan imunohistokimia dengan antibodi cyclin D1 pada kelompok adenokarsinoma low grade $(A, B)$ dan high grade $(C, D)(400 x)$.

Keterangan: A. Pulasan HE dari adenokarsinoma low grade; B. Ekspresi cyclin D1 pada adenokarsinomama low grade, terpulas coklat pada inti sel tumor (tanda panah merah); C. Pulasan HE dari adenokarsinoma high grade; D. Ekspresi cyclin D1 pada adenokarsinoma high grade, terpulas coklat pada inti sel tumor (tanda panah merah).

Hubungan antara Ekspresi Protein Cyclin D1 dengan Grading Adenoma

Hubungan antara ekspresi protein cyclin D1 dengan grading adenoma (low grade dan high grade) dianalisis dengan uji korelasi Spearman (karena merupakan data ordinal). Hasil analisis menunjukkan angka signifikansi sebesar 0,502 ( $p>0,05)$, yang berarti tidak terdapat hubungan yang signifikan antara ekspresi cyclin D1 dengan grading adenoma kolorektal.

\section{Hubungan antara Ekspresi Protein Cyclin D1 dengan Grading dan Stadium Adenokarsinoma}

Hubungan antara ekspresi protein cyclin D1 dengan grading adenokarsinoma dianalisis dengan uji korelasi Spearman. Hasil analisis menunjukkan angka signifikansi sebesar 0,661 $(p>0,05)$ yang menunjukkan tidak terdapat hubungan yang signifikan antara ekspresi cyclin D1 dengan grading adenokarsinoma (low grade dan high grade). Demikian halnya korelasi antara ekspresi protein cyclin D1 dengan stadium adenokarsinoma berdasarkan klasifikasi Dukes, hasil uji menunjukkan angka signifikansi sebesar 0,905 ( $p>0,05)$. Hasil tersebut menunjukkan tidak terdapat korelasi yang signifikan antara ekspresi protein cyclin D1 dengan stadium adenokarsinoma kolorektal berdasarkan klasifikasi Dukes.

\section{Pembahasan}

Karakteristik sampel penelitian yang dianalisis berdasarkan pengelompokan jenis kelamin, pada kelompok adenoma sebanyak 
53,3\% didapatkan pada laki-laki dan sedikit predominasi pria dibandingkan wanita dengan rasio $1,2: 1$. Data ini sesuai dengan literatur dan hasil penelitian sebelumnya yang menyatakan bahwa kasus adenoma sedikit lebih sering didapatkan pada pria. ${ }^{14,15}$ Penelitian lain menyebutkan adenoma maupun adenokarsinoma lebih jarang terjadi pada wanita karena berhubungan dengan efek proteksi hormon seks yang dalam hal ini diperankan oleh kombinasi estrogen dan progesteron. ${ }^{16}$

Kelompok adenokarsinoma lebih didominasi wanita yaitu sebesar $60 \%$, berbeda dengan hasil dari beberapa penelitian sebelumnya, termasuk penelitian retrospektif yang dilakukan di instalasi yang sama oleh peneliti, yang menunjukkan bahwa tidak didapatkan perbe-daan jenis kelamin pada angka kejadian adenoma maupun adenokarsinoma. Hal ini bisa disebabkan karena perbedaan karakteristik sampel yang dilibatkan. ${ }^{17,18,19}$

Berdasarkan pengelompokan usia, baik kasus adenoma maupun adenokarsinoma terbanyak dijumpai pada usia 55 tahun, hal ini sesuai dengan beberapa penelitian sebelumnya yang menyatakan bahwa kasus keduanya banyak terjadi pada usia di atas 50 tahun dengan puncak 51-60 tahun. Peningkatan insiden pada usia tua dapat terjadi karena akumulasi mutasi somatik yang disebabkan berkembangnya neoplasma dan juga dipengaruhi oleh faktor imunitas seiring bertambahnya usia. Hasil ini juga sesuai dengan data dari WHO yang menyebutkan bahwa insiden karsinoma kolorektal meningkat seiring dengan bertambahnya usia dan jarang terjadi pada usia di bawah 40 tahun, kecuali pada individu dengan predisposisi genetik atau suatu kondisi predisposisi seperti inflammatory bowel disease yang kronis. ${ }^{20,21,22,23}$

Lokasi terbanyak adenoma adalah rektosigmoid, hasil ini sesuai dengan banyak penelitian sebelumnya yang menyatakan bahwa lokasi tersering dari adenoma adalah daerah rektosignoid. Sedangkan hasil untuk kelompok adenokarsinoma pada penelitian terbanyak di daerah colon ascenden, hasil ini tidak sesuai dengan penelitian retrospektif oleh peneliti yang dilakukan sebelumnya di instalasi yang sama, yaitu dari 300 kasus adenokarsinoma pada tahun 2016-2018 didapatkan sebanyak $62 \%$ adenokarsinoma terletak di daerah rektosigmoid. Hal ini kemungkinan disebabkan oleh perbedaan sampel penelitian yang digunakan. Sebagaimana disebutkan di beberapa literatur bahwa rektum dan sigmoid merupakan lokasi tersering (50-60\%), disusul kemudian daerah colon ascenden $(9 \%)$, caecum $(8 \%)$, colon descenden $(5 \%)$ dan colon transversum (4\%). $4,18,24,25$

Rerata ekspresi cyclin D1 pada kelompok adenoma adalah sebesar $31,18 \%$ dan kelompok adenokarsinoma sebesar 46,69\%. Hasil analisis uji beda dengan independent $t$ test dari kedua kelompok sampel tersebut menunjukkan angka signifikansi $p<0,01$, artinya terdapat perbedaan ekspresi yang signifikan di antara keduanya. Hasil penelitian ini sesuai dengan penelitian oleh Albasri (2019), yang membandingkan hasil microarray antara kelompok mukosa kolon normal, adenoma dan adenokarsinoma. Tidak didapatkan overekspresi cyclin D1 pada mukosa normal, namun meningkat bertahap pada kelompok adenoma dan adenokarsinoma. ${ }^{25}$ Hal ini memperlihatkan bahwa protein cyclin D1 berperan dalam karsinogenesis pada kanker kolorektal. Sebagai salah satu protein yang memegang peranan penting pada progresi fase $\mathrm{G} 1$ ke $\mathrm{S}$ pada siklus sel, cyclin D1 diketahui meningkat ekspresinya pada bebe-rapa tumor, dan ditemukan terjadi pada lebih dari sepertiga kasus kanker kolorektal. Di samping telah banyak penelitian yang sudah membuktikan hal tersebut secara in situ dengan pengecatan imunohistokimia, beberapa studi juga telah meneliti ekspresi gen cyclin D1 atau mRNA 
dengan metode Southern Blotting maupun $R T$ -PCR. Bahnassy et al., (2004) dalam Li et al., (2014) menemukan adanya amplifikasi gen cyclin D1 pada 50 kasus kanker kolorektal yang diteliti, dan menemukan amplikasi tersebut berhubungan secara signifikan dengan stadium lanjut dari kanker kolorektal. ${ }^{26}$

Pada penelitian ini, tidak terdapat hubungan yang signifikan antara cyclin D1 dengan grading pada adenoma. Hasil penelitian ini berbeda dengan penelitian lain sebelumnya yang menunjukkan terdapat hubungan antara ekspresi cyclin D1 dengan grading dari adenoma. ${ }^{15}$ Pada beberapa literatur menjelaskan bahwa adenoma dengan gambaran high grade merupakan adenoma yang berisiko mengalami transformasi menjadi ganas, namun hal ini bukan suatu kepastian karena pada beberapa kasus karsinoma berasal dari adenoma low grade. ${ }^{27}$ Fakta ini mendukung hasil penelitian ini yaitu tidak didapatkan hubungan yang signifikan antara cyclin D1 dengan grading pada adenoma.

Grading dan derajat diferensiasi mempunyai peran sebagaimana stadium tumor yaitu suatu faktor prognostik dari kanker kolorektal, sehingga tumor dengan gambaran high grade atau poorly differentiated sering dihubungkan dengan prognosis buruk. Pilihan terapi dan penentuan prognosis juga sangat tergantung pada saat stadium pertama kali pasien terdeteksi. Stadium awal penyakit sering diterapi dengan hanya pembedahan, stadium lebih lanjut atau yang sudah metastasis pada umumnya memerlukan tambahan kemoterapi atau terapi target, baik terpisah maupun digunakan sebagai kombinasi. 27,28

Hasil analisis pada penelitian ini juga menunjukkan tidak terdapat hubungan yang signifikan antara ekspresi cyclin D1 dengan stadium adenokarsinoma. Hal ini bertentangan dengan penelitian sebelumnya yang menunjukkan hubungan signifikan antara cyclin D1 dengan stadium lanjut dalam hal ini Dukes C1, C2 dan D. Sedangkan penelitian lain yang meneliti peran dari 3 tipe cyclin (D1,D2 dan D3), memberikan bukti bahwa di antara ketiga tipe tersebut, yang paling berhubungan dengan peningkatan stadium kanker adalah protein cyclin D1, dan yang paling berhubungan dengan derajat diferensiasi (grading) adalah cyclin D1. ${ }^{26,29}$

Penelitian lain juga menyebutkan bahwa lokasi cyclin D1 berpengaruh terhadap efek yang ditimbulkan. Ekspresi cyclin D1 di inti sel lebih berpengaruh terhadap proliferasi, sedangkan ekspresi pada sitoplasma lebih berpengaruh terhadap kemampuan adesi sel, migasi sel dan metastasis jauh. ${ }^{30}$ Penelitian ini hanya memperhitungkan ekspresi cyclin D1 pada inti sel tumor, sehingga bisa menjadi salah satu faktor perancu penyebab tidak didapatkannya hubungan yang signifikan dengan stadium adenokarsinoma.

Meskipun banyak studi telah dilakukan untuk melihat ekspresi protein cyclin D1 pada kanker kolorektal, namun kesimpulan yang didapatkan masih sangat bervariasi. Hal ini karena sebagian besar penelitian menggunakan metode imunohistokimia, maka ketidakseragaman hasil sangat bisa dipengaruhi oleh cara penetapan penghitungan baik kuantitatif maupun semikuantiatif yang memang belum terstandarisasi. Faktor lain adalah jumlah sampel, serta teknik yang digunakan. 12,15,29

Kelebihan dari penelitian ini adalah penghitungan ekspresi cyclin D1 dilakukan dengan metode kuantitatif yaitu dengan menghitung per sel, sehingga dapat meminimalkan bias penghitungan, karena sebagian besar penelitian yang melibatkan ekspresi cyclin D1 dengan menggunakan teknik imunohistokimia menilai ekspresi dengan metode kualitatif (menggunakan skoring dan melihat intensitas pewarnaan).

Keterbatasan penelitian ini yang bisa menjadikan faktor perancu adalah sediaan biopsi adenoma yang sebagian besar hanya berupa jaringan biopsi yang berukuran kecil, 
dan hanya beberapa sampel yang berupa sediaan polipektomi, sehingga apabila dilakukan penelitian yang relevan perlu melibatkan disiplin ilmu lain seperti IImu Penyakit Dalam dan Bedah Digestif.

\section{Kesimpulan}

Penelitian ini nenunjukkan ekspresi protein cyclin D1 yang berbeda signifikan antara adenoma dan adenokarsinoma, namun ekspresi tersebut tidak berhubungan dengan grading adenoma maupun grading dan stadium adenokarsinoma. Dapat dikatakan bahwa cyclin D1 dapat digunakan untuk membedakan antara adenoma dan adenokarsinoma kolorektal, namun ekspresi cyclin D1 tersebut tidak berhubungan dengan grading dan stadium tumor dari keduanya.

\section{Saran}

Perlu penelitian lanjutan dengan sampel yang lebih banyak dan multidisiplin ilmu, untuk menentukan nilai cut off point ekspresi cyclin D1 yang bisa membedakan antara adenoma dan adenokarsinoma kolorektal.

\section{Daftar Pustaka}

1. Siegel R, Desantis $C$, Jemal $A$. Colorectal Cancer Statistic, 2014. CA Cancer J Clin. 2014; 64(2):104-17.

2. Dragovich T. Colon Cancer. (Online). 2019. http://emedicine.medscape.com/ article/277496-overview. [accessed $5^{\text {th }}$ June 2019].

3. Hamza AH, Aglan HA, Ahmed HH. Recent Concepts in the Pathogenesis and Management of Colorectal Cancer. Recent Advanced in Colon Cancer. 2017. Chapter 6.

4. Shussman $N$ and Wexner SD. Colorectal Polyps and Polyposis Syndrome. Gastroenterology Report. 2014; 2(1):1-15.

5. Conteduca V, Sansonno D, Russi S, Dammacco F. Precancerous Colorectal
Lesion (Review). International Journal of Oncology. 2013; 43(4):973-984.

6. Simon K. Colorectal Cancer Development and Advances in Screening. Clinical Intervention in Aging. 2016; 11:967-976.

7. Romero JJG, Trevino AIV, Flores EHC, Mera BB, Enriquez MH, Ruiz KU, et al. Colorectal Cancer: A Review. International Journal of Research in Medical Sciences. 2017; 5(11):4667-4676.

8. Pestell RG and Li. Antisense to Cyclin D1 Inhibits VEGF-Stimulated Growth of Vascular Endothelial Cells: Implication of Tumor Vascularization. Clin Cancer Res. 2006; 12(15):4720.

9. Li Z, Wang C, Prendergast G, Pestell RG. Cyclin D1 Functions in Cell Migration. Cell Cycle. 2006; 5(21):2440-2442.

10. Dai $M$, Al-Odaini AA, Fils-Aime N, Villatoro MA, Guo J, Arakelian A. et al. Cyclin D1 Cooperates with p21 to Regulate TGF $\beta$ Mediated Breast Cancer Cell Migration and Tumor Local Invasion. Breast Cancer Research. 2013; 15:R49.

11. Wangefjord S, Manjer J, Gaber A, Nodin B, Eberhard J, Jirstrom K. Cyclin D1 Expression in Colorectal Cancer is a Favorable Prognostic Factor in Men but Not in Women in a Prospective, Population-Based Cohort Study. Biology of Sex Differences. 2011; 2:10.

12. Jang KY, Kim YN, Bae JS, Chung MJ, Moon WS, Kang MJ, et al. Expression of Cyclin D1 is Associated with $\beta$-Catenin Expression and Correlates with Good Prognosis in Colorectal Adenocarcinoma. Translational Oncology. 2012; 5(5):370378.

13. Ahlin $\mathrm{C}$, Lundgren $\mathrm{C}$, Embretsen-Varro $\mathrm{E}$, Jirstrom K, Blomqvist C, Fjallskog M. High Expression of Cyclin D1 is Associated to High Proliferation Rate and Increased Risk of Mortality In Women with ERPositive but Not in ER-Negative Breast Cancers. Breast Cancer Res Treat. 2017; 164(3):667-678. 
12. Kumar V, Abbas AK, Aster JC. Robbins Basic Pathology. $9^{\text {th }}$ Edition. Philladelphia: Elsevier Sanders. 2015.

13. Nassrat FL, Ali HH, Qasim BJ. Immunohistochemical Expression of Cyclin D1 in Colorectal Adenomas: a Clinicopathological Study. Kasr Al Ainy Medical Journal. 2016; 22(3):115-122.

14. Meijer BJ, Wielenga MCB, Hoyer PB, Amos-Landgraf JM, Hakvoort TBM, Muncan V, et al. Colorectal Tumor Prevention by the Progestin Medroxyprogesterone Acetate is Critically Dependent on Postmenopausal Status. Oncotarget. 2018; 9(55):30561-30567.

15. El-Taher SM, Alenezy A, Salama BMM, Hassan TMM. Risk Factors of Colorectal Cancer; A Case-Control Study. The Egyptian Journal of Community Medicine. 2016; 34(1).

16. Goldblum JR, Lamps LW, Kenney JK. Rosai and Ackerman's Surgical Pathology. 11th Edition. Philadelphia: Elsevier Inc. 2018.

17. Rosidah A, Norahmawati E, Anita KW. Profil Klinikopatologi Pasien Adenoma dan Adenokarsinoma Kolorektal di Instalasi Patologi Anatomi RSUD Saiful Anwar Malang Periode 2016-2018. Penelitian Retrospektif. 2019.

18. Silva SM, Rosa VF, Santos ACN, Almeida RM, Oliveira PG, Sousa JB. Influence of Patient Age and Colorectal Polyp Size on Histopathology Finding. $A B C D$ Arg Bras Cir Dir. 2014; 27(2):109-113.

19. Strum WB. Colorectal Adenoma. N Engl J Med. 2016; 374(11):1065-75.

20. Pantow PR, Waleleng JB, Sedli PB. Profil Adenocarcinoma Kolon di RSUP Prof. Dr. R. D. Kandou dan Siloam Hospitals Periode Januari 2016-Juni 2017. Jurnal eClinic (eCl). 2017; 5(2):326-331.
21. Hamilton SR, Bosman FT, Boffeta $P$, llyas $\mathrm{M}$, Moreau $\mathrm{H}$, Nakamura $\mathrm{Sl}$, et al. Carcioma of the Colon and Rectum. WHO Classification of Tumors of the Digestive System. WHO Press. 2010; 131-182.

22. Hachmanoochehry F, Asefzadeh S, Kazemifar AM, Ebtehaj M. Clinicopathological Feature of Colon Adenocarcinoma in Qazvin, Iran: A 16 Year Study. Asian Pac J Cancer Prev. 2014; 15 (2):951-955.

23. Albasri AA, Elkablawy MA, Ansari IA, Alhujayli AS. Prognostic Significance of Cyclin D1 Over-Expression in Colorectal Cancer: An Experience in Madinah, Saudi Arabia. Asian Pac J Cancer Prev. 2019; 20(8):2471.

24. Li Y, Wei J, Xu C, Zhao Z, You T. Prognostic Significance of Cyclin D1 Expression in Colorectal Cancer: A MetaAnalysis of Observational Studies. PLOS ONE. 2014; 9(4).e94508.

27. Salmo $E$ and Haboubi N. Adenoma and Malignant Colorectal Polyp: Pathological Considerations and Clinical Applications. EMJ Gastroenterol. 2018; 7(1):92-102.

28. Nguyen $H T$ and Duong $H Q$. The Molecular Characteristics of Colorectal Cancer: Implications for Diagnosis and Therapy (Review). Oncology Letters. 2018; 16(1):9-18.

29. Mermelshtein A, Gerson A, Walfisch $S$, Delgado B, Shechter G, Delgado J, et al. Expression of D-type Cyclins in Colon Cancer and in Cell Lines from Colon Carcinomas. Br J Cancer. 2005; 93(3): 338-345.

30. Fuste NP, Fernandez-Hernandez $R$, Cemeli T, Mirantes C, Pedraza N, Rafel $\mathrm{M}$, et al. Cytoplasmic Cyclin D1 Regulates Cell Invasion and Metastasis Through the Phosphorylation of Paxillin. Nature Communication. 2016; 7:11581. 